\title{
TEACHER'S PERSPECTIVE ON THE IMPACT OF POLITENESS STRATEGIES IN THE INDONESIAN ENGLISH TEXTBOOK ON STUDENT'S COMMUNICATIVE COMPETENCE
}

\author{
Ayu Meiratnasari ${ }^{{ }^{*}}$ \\ Agus Wijayanto $^{2}$ \\ Suparno ${ }^{3}$ \\ Universitas Muhammadiyah Surakarta, Surakarta, Indonesia \\ 1ayumeiratnasari@gmail.com \\ 2aguswijayanto@ums.ac.id \\ ${ }^{3}$ drs.suparno@rocketmail.com
}

Manuscript received 16 September 2019

Manuscript accepted 15 June 2020

*Corresponding author

https://doi.org/10.33736/ils.1807.2020

\begin{abstract}
The purpose of this study was to investigate teacher's perspectives of the impact of politeness strategies in the Indonesian English textbooks on student's communicative competence. The participants were two English teachers who taught in one of the senior high schools in Yogyakarta, Indonesia and five students. Discourse analysis of the interview data was conducted. The results showed that the teachers have a positive point of view about the authority of politeness strategies, reflected in Indonesian English textbooks, on their student's communicative competence. Unfortunately, the teachers could not explain in more detail the aspects of communicative competence which could be influenced by politeness strategies in the English textbooks. The interviews with the students indicated that politeness strategies reflected in their English textbooks supported the student's linguistic competence and strategic competence.
\end{abstract}

Keywords: Politeness strategies, teacher's perspective, communicative competence, textbook 


\section{Introduction}

Due to technological communication advancements, researchers are interested to investigate the use of politeness strategies in communication during the last two decades. This phenomenon is due to the enlargement of communication (Saidi \& Khosravi, 2015). For instance, the study on politeness strategies in digital communication involving American, Japanese, Malaysian, Mexican, and Spanish students revealed that politeness strategies: (1) encourage interpersonal communication, (2) maintains harmonious relations, (3) establish norms of communication, (4) sustain social relationships, and (5) helps to achieve the communicative goals (Adel, Davoudi, \& Ramezanzadeh, 2016; Flores-Salgado \& Castineira-Benitez, 2018; Kavanagh, 2016; Li, 2012; Maros \& Rosli, 2017; Schneider, Nebel, Pradel, \& Rey, 2015)

The practice of politeness strategies in the English classroom context also leads to effective classroom interaction. However, cultural issues can influence the application of politeness strategies (Kurdghelashvili, 2015; Mahmud, 2019). The concern of politeness strategies is also found in English textbooks. Gholami's (2015) analysis of Iranian EFL textbooks revealed that four politeness strategies are found in the Iranian EFL textbooks. He also suggested that the textbooks developers have to work more pragmatic knowledge into Iranian EFL textbooks to enable students to develop politeness strategies. Alcoberes (2016) analysed English textbooks in Southeast Asia. They revealed that the Indonesian English textbooks contain materials which teach cynical politeness strategy. However, the teacher perspective on politeness in textbooks has not been researched.

This study investigated the teacher's perspective on the importance of politeness strategies reflected in English textbooks and how it influences development of student's communicative competence. The teacher's perspective is essential to investigate because the teacher is one of the facilitators who determine the kinds of materials to use in the learning process. Macalister and Nation (2010) stated that teachers should settle on what kind of language features and skills they have to teach and which sourcebooks they have to use in the learning process.

\section{Review of Literature}

\section{Politeness Strategies}

Politeness is a manner of maintaining the feeling of others during communication to avoid conflict (Brown, 2015; Leech, 1983). Brown and Levinson (1987) classified politeness strategies into bald on-record, positive politeness, negative politeness, and off-record. Teaching politeness will help students to use various speech acts to make social interaction and build a good relationship (Tsakona, 2016). Teaching politeness seems vital for the students, but in the teaching and learning process, the teachers need some materials and sources to support the process of teaching and learning. As Gholami (2015) and Alcoberes (2016) have found, politeness strategies are included in English textbooks. 
Politeness strategies in written discourse have also been studied. Qian and Pan, (2017) examined politeness strategies in 600 business letters written by students in Hong Kong and Shanghai. The results indicated that the students used politeness strategies in make the business letters sound diplomatic, and the writing tone soft and objective. Another research by Edstrom and Ewald (2019) found that politeness strategies employed in auto-reply emails dominated the permutation of bald-on records and positive politeness. It used to help the reader find the information directly with pleasure. Moreover, Pham and Yeh (2020) examined the politeness of Vietnamese students in writing emails. Their study revealed that Vietnamese students employed a high level of imposition, such as using formal terms of address. The formal address form is included as negative politeness to give deference and show respect to the professor.

\section{Textbook}

The textbook is a resource of materials and activities which can be used as reference and syllabus to support teachers in the teaching and learning process (Cunningsworth, 1995). The textbook provides pragmatic input through various materials such as dialogs, visuals, tasks, and exercise. It can also be used in various ways, depending on the teacher's teaching style or student's learning style (Limberg, 2016). Recently, many foreign language textbooks facilitate intercultural understanding. For example, an English textbook for the international market might inform the learners that Japanese people value respectful communication so the learners get the knowledge to maintain harmony in social relations (McConachy, 2018). Graves (2000) and Richards (2017) explained some criteria of an excellent coursebook:

1. A right coursebook may cover authentic materials.

2. It has to fulfil the learner's needs.

3. The textbook has to be suitable for the objective of a language learning programme.

4. The textbook can be used in flexible ways.

5. The textbook supports the learning process and mediate the target language and the learners.

\section{Communicative Competence}

Communicative competence is the ability of people to know when to speak formal or informal. They know the context and how to express their idea clearly during the communication, considering the relation between interlocutors (Hymes, 1972; Kalymbetova, Kulsariyeva, \& Massalimova, 2015; Whyte, 2019). Besides the grammatical rules, appropriateness in communication is vital (Canale \& Swain, 1980; Fan, 2019). There are six competencies in communicative competence (Canale \& Swain, 1980; Celce-Murcia, Eghtesadi, 2017; Hymes, 1972; Littlewood, 2011):

1) Linguistic competence. It includes the essential elements of communication such as the sentence patterns and types, vocabulary

Teacher's Perspective on the Impact of Politeness Strategies in the Indonesian English Textbook on Student's Communicative Competence 
knowledge, grammar, the morphological inflection, semantic and phonology, that have been established to focus on second language learning to realise communication as speech or writing (Littlewood, 2011).

2) Discourse competence. It enables a person to engage in selecting, sequencing and arranging words, structure, sentences, and utterances to achieve unified spoken and written text (Eghtesadi, 2017).

3) Sociocultural competence. It refers to the speaker's knowledge of how to express messages appropriately with the awareness of the cultural knowledge and assumptions that affect the exchange of meaning and may lead to misunderstanding in intercultural communication.

4) Sociolinguistic competence. It consists of the basic knowledge of how to use language appropriately in social situations such as conveying suitable degrees of formality, directness, and so on (Eghtesadi, 2017; Fauziati, 2016).

5) Strategic competence. It is the knowledge of communication strategies and how to use them.

6) Pragmatic competence. It enables second language speakers to use their linguistic resources to convey and interpret meanings in real situations, including those where they encounter problems due to gaps in their knowledge.

\section{Method}

The study applied a descriptive qualitative approach. The participants are two English teachers at one of senior high school in the countryside of Yogyakarta, Indonesia. The first teacher teaches first-grade students, and the second teacher teaches second- and third-grade students. They have more than 10 years' experience in teaching English for senior high school. Besides, five students voluntarily participated in the study, and were also interviewed.

In this study, the researcher applied three steps to the research, such as data preparation, data collection, and data processing. In the data preparation, the researcher gained information about the title of English textbooks used in this school by asking the teacher and the students. The title of English textbooks that the first-grade students use is "Talk Active 1" and the second-grade student used "Talk Active 2". Then, the researcher read the textbooks to measure politeness strategies in the textbooks. Then the researcher constructed five interview questions for the teachers and four questions for the students to investigate their perspective on politeness in English textbooks.

The teacher interviews were completed in three days. The interview was recorded using a smartphone. This was followed by the student interviews. The interview with the students aimed to confirm the teacher's perspective, as data triangulation to validate the data.

The interviews were transcribed and translated into English as the interviews were conducted in the Indonesian language. The interview translation was processed in some steps. First, the researcher translated the interview Teacher's Perspective on the Impact of Politeness Strategies in the Indonesian English Textbook on Student's Communicative Competence 
transcription by herself. Second, the researcher also sent the original interview transcripts to the translation service. Third, the researcher compared the translated interviews and revised the interview transcript that was done by the researcher. Fourth, the researcher sent all of the transcriptions, including the revised version to the researcher's advisors for checking. Last, the researcher generated some revisions of the transcriptions based on the advisor's recommendations. The discourse analysis method was applied to analyse the data. Discourse analysis has many different kinds of approaches.

\section{Results and Discussion}

\section{The Teacher's Perspective on the Politeness Strategies in the English textbook}

In this section, the researcher provides extracts of transcripts from the interviews with teachers.

\section{Extract 1}

Q: Do you know about politeness strategies?

T1: Yeah, I only know it in general. However, I can differentiate a polite or impolite expression.

T2: Honestly, this is my first time; however, after making a quick reading on the internet, I have some representation.

In Extract 1, T1 informed me that she had a little background knowledge about politeness strategies. Then, $\mathrm{T} 2$ said that she did not know politeness strategies, but tried to gather the knowledge through the internet when the researcher was conducting the interview. The teachers seem to not have in-depth knowledge of politeness strategies, and only know politeness in general. However, it does not mean they cannot present their perspective about the importance of politeness reflected in English textbooks. Discover the teacher's perspective on politeness strategies in Extract 2:

\section{Extract 2}

Q: Based on your perspective, is politeness strategies essential to reflect in English textbooks?

T1: Yes, it is crucial. English is a foreign language; it has to adjust to the Indonesian culture. For example, Indonesian people concern about power relations when we are communicating. We have to use polite expressions when we speak with our seniors or our teachers. So, I think it is essential to reflect politeness strategies in the textbooks since the students use it to learn.

T2: I think it is crucial. There is a formal and informal language that influences whom the students speak. If they speak with older people, they have to use more polite expressions. However, if they speak with their friend or the younger, the students may use casual language. In this case, a textbook is used as a student's learning source. That is why I think it is vital to reflect politeness in English textbooks.

Teacher's Perspective on the Impact of Politeness Strategies in the Indonesian English Textbook on Student's Communicative Competence 
Extract 2 shows that it is essential to include politeness strategies in English textbooks for reasons such as cultural issues and power relations. T1 stated politeness strategies in English textbooks have to reflect Indonesian culture and the concern with power relation in communication. $\mathrm{T} 2$ had the same view on power relations and politeness strategies, but the cultural issue was not a concern for her. Moreover, the coursebook is a student's learning source, which is why politeness strategies should be reflected in English textbooks.

\section{Extract 3}

Q: Based on your point of view, may politeness strategies reflected in English textbooks influence student's communicative competence?

T1: Yes. The students can distinguish polite and impolite expression. So, they will pay less rude when using English. The students more often use "could you close the window, please" when they are asking help to their friend.

T2: It should be yes, which means that if the students practice what they have learned, it will influence their communicative competence.

Extract 3 shows that politeness strategies reflected in English textbooks influence the student's communicative competence. T1 said that her students are less rude when using English, such as using negative politeness strategies expressions such as "could you close the window, please." T2 had the same point of view. Her students had learned about politeness strategies through the textbooks and if practise what they learnt, it will have a good impact on their communicative competence.

\section{Extract 4}

Q: May politeness strategies reflected in English textbooks support student's communicative competence?

T1: Yes, it may.

T2: Yes, in case of attitude. In our curriculum, one of the aspects that have to value is the student's attitude. So, in the English subject context, one aspect of attitude which will be valued by the teacher is how their expression to communicate with the teacher. Is it in a polite or impolite way? For example, when the students ask permission to the teacher, they use the following expression "pardon me, would you let me wash my hand?".

Extract 4 emphasises that politeness strategies support the student's communicative competence. T2 explained that it would support the students to have better attitudes when communicating with the teacher. The teacher also gave an example of her students asking permission gently with expression such as "pardon me, would you let me wash my hand?" That expression is considered as negative politeness.

\section{Extract 5}

Q: Can politeness strategies, which reflected in English textbooks, be used as a guide for students in communication?

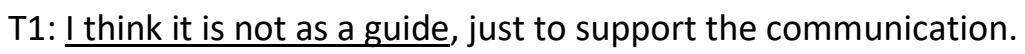

Teacher's Perspective on the Impact of Politeness Strategies in the Indonesian English Textbook on Student's Communicative Competence 
T2: It should be possible. Politeness strategies are reflected in the example and materials of expressions in textbooks. I was a teacher who also always explain about politeness to the students when the materials are containing politeness strategies. Besides, they also have practiced it in the learning process, so it should be they use as a guide in their daily life. In my opinion, what we learn as knowledge has to use as our guide in real life.

In Extract 5, T1 stated that the inclusion of politeness strategies reflected in English textbooks can only support the student's communicative competence. On the other hand, $\mathrm{T} 2$ felt that the students can use their knowledge as a guide in their daily communication.

The researcher found that the teacher has general knowledge about politeness strategies based on the teachers' interview responses. Moreover, the teachers believed that politeness strategies influence and support their students' communicative competence. Unfortunately, the teachers seemed uncertain in some aspects. They were not sure which aspect of student's communicative competence was influenced by politeness strategies. So, the researcher decided to interview the students who taught by the teachers and the results are reported in the next section.

\section{Student's Perspective on Politeness Strategies in the English Textbook}

In this section, excerpts from interviews with students are included. Three out of five students said that their English teachers explained about polite and impolite expressions (Extract 6).

\section{Extract 6}

Q: Have you learned or know about politeness strategies?

S1: Yes, my teacher ever explain about polite and impolite expression.

S2: Yes, I have learned it, but just in general, my teacher ever have explained it .

S3: Yes, I have learned it from my teacher.

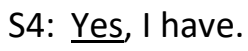

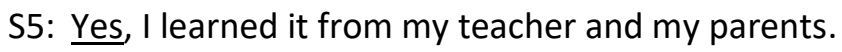

Extract 7 shows students' view that learning politeness strategies is crucial for them to show respect when they communicate with older people. Due to English being a foreign language for Indonesian, it is crucial to learn politeness and impolite expressions to avoid conflicts in the communication, especially when they speak with native speakers.

\section{Extract 7}

Q: Do you think politeness strategies are essential to be reflected in the English textbook and to be learned by the students?

S1: $\underline{\text { Yes, }}$, because politeness in communication is fundamental.

S2: $\underline{\text { Yes, }}$, it is essential because the native speaker of English has a different culture with us or Indonesia, so we need to use politeness strategies to avoid misunderstanding during communication.

Teacher's Perspective on the Impact of Politeness Strategies in the Indonesian English Textbook on Student's Communicative Competence 
S3: $\underline{\text { Yes, }}$, it is crucial because the students have to know the polite and impolite expression in English.

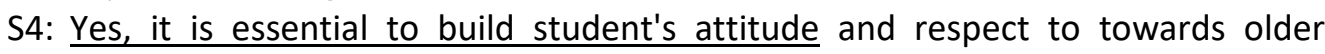
person.

S5: Important. It makes the students practice to communicate politely during the communication with the older person.

Extract 8 shows that the students are aware of the presence of politeness strategies in their English textbooks because they can mention pages which contain an exercise on it. Figure 1 shows task 13 on page 26 and task 1 on page 39. The task is about completing a dialogue, but the expressions for politeness strategies are included in the dialogue (Figure 2). In the dialogue between Djokovic and Federer, Federer answered "Thank you, man" and this reflects positive politeness. According to Brown and Levinson (1987), the use of address forms such as "man" is considered the realisation of positive politeness strategies which is used to soften facethreatening acts.

\section{Extract 8}

Q: Are politeness strategies reflected in the English textbook that you used?

S1: $\underline{\text { Yes}}$, for example in page 26 task 13

S2: Yes, on page 39 task 1

S3: $\underline{\text { Yes, }}$, on page 27 task 15

S4: $\underline{\text { Yes, }}$, activity 6 , pages 6

S5: $\underline{\text { Yes, in page } 4 \text { activity } 1}$, page $\underline{7 \text { activity } 9}$, and page $\underline{8 \text { activity } 10}$
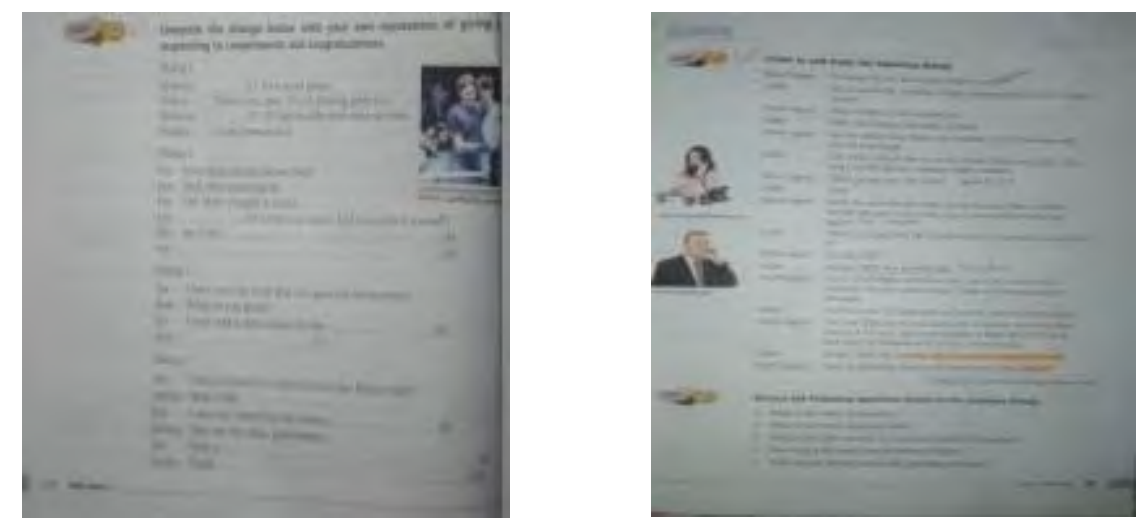

Figure 1. "Talk Active 1" page 26 on the left, and "Talk Active 1" page 39 on the right

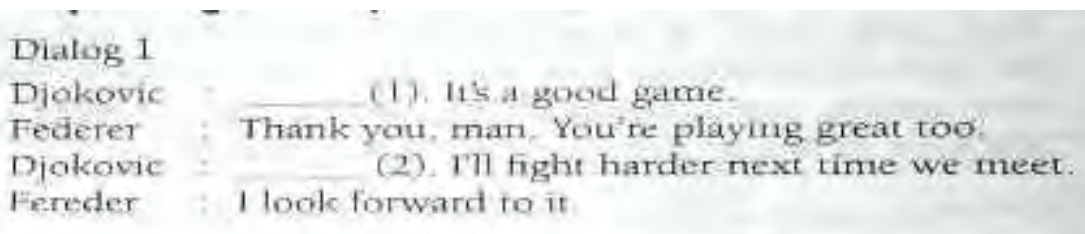

Figure 2. Dialogue 1 in Task 13 with expressions for politeness strategies

Teacher's Perspective on the Impact of Politeness Strategies in the Indonesian English Textbook on Student's Communicative Competence 
Based on Brown and Levinson (1987), the expression "could I have your name, please?" is considered as the realisation of negative politeness which used to convey the speaker's indirect request to the hearer (see Figure 3 ). Then, the expression "Let me see" in Figure 4 is considered as a bald on-record politeness strategy, which used to convey the great urgency or desperation. The travel agent's reply ("Well, the price for the flight on the day you was is almost double the price you would pay if you could leave the day after") is considered an off-record politeness strategy, which is used to emphasise that the amount is higher than the actual flight fare. The use of "almost double" in the expression showed that the flight price is higher than the original price, but the double price may be cheaper.

\section{Caller Alright, And, uh, I would like to request a vegetarian meal. \\ Iravel Agent : Sure, no problem. And could thave your name, please?}

Figure 3. Dialogue in Task 1

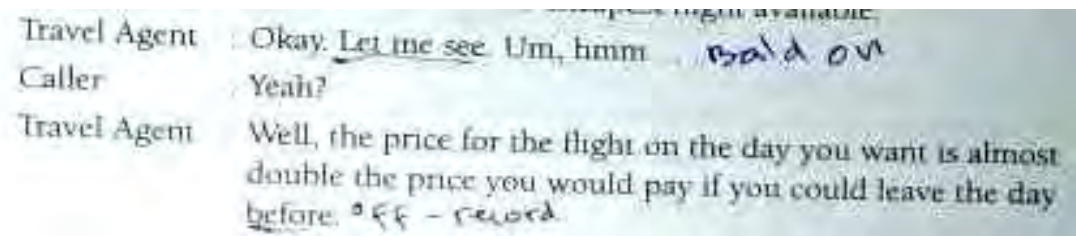

Figure 4. Dialogue in Task 1

Similar kinds of politeness strategies are found in the English textbook Talk Active 2 (Figure 6). First, the expression "its Rosa's birthday next week" is an offrecord politeness strategy used to give a hint for uttering purposes to do something. Second, the expression "Let's buy her a present!" is considered as the realisation of bald on-record politeness strategies used to convey the great urgency or desperation. Third, the expression "Great idea!" is considered a reflection of a positive politeness strategy used to express exaggeration. Words such as "marvellous", "incredible", and "fantastic" and "great" express exaggeration.

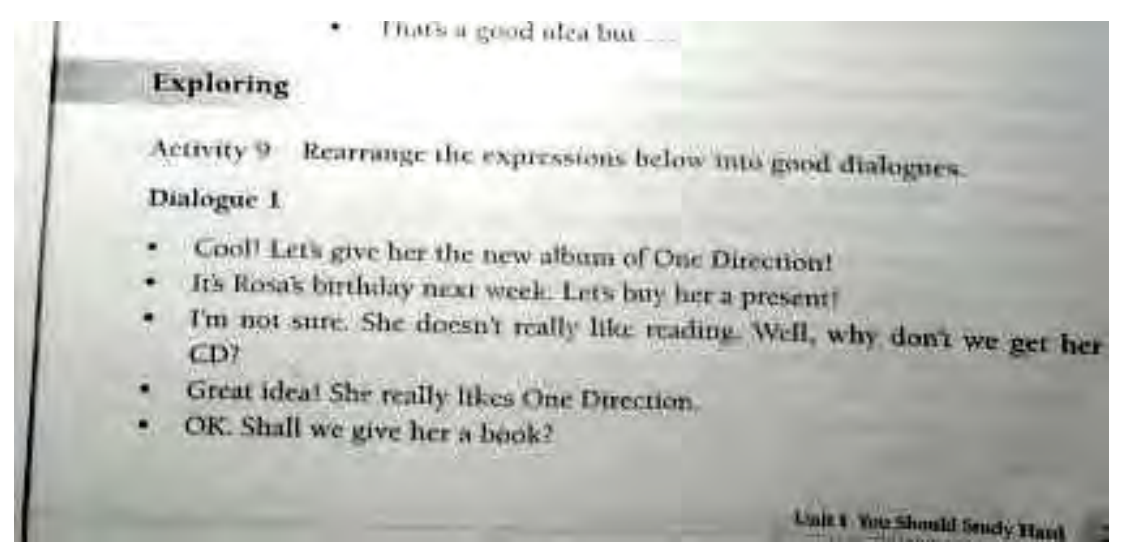

Figure 5. Page 7 in Talk Active 2

Teacher's Perspective on the Impact of Politeness Strategies in the Indonesian English Textbook on Student's Communicative Competence 
Extract 9 shows that the students felt that politeness strategies in their English textbook influence their communicative competence. Most of the students said that it controls their way of speaking English. They are more careful in word choice, intonation, and the way they speak. It also makes them analyse their partner's reaction during the communication.

\section{Extract 9}

Q: May politeness strategies reflected in your English textbook influence and support your communicative competence?

S1: Yes, I am more careful when I am speaking in English. I'll pay attention to my intonation.

S2: Yes, for example in selecting words and the way I am speaking.

S3: Yes, it influences me in the way I'm speaking and make me consider my partner reaction during the communication.

S4: Yes, it may be. I think it controls the way I am speaking.

S5: Yes, it influences the way I am speaking with tourist.

\section{Discussion}

This study examined the teacher's perspective on the significance of politeness strategies reflected in English textbooks on student's communicative competence. The results showed that the teachers believe politeness strategies reflected in the English textbooks can influence and support their student's communicative competence. Unfortunately, the teacher cannot identify specific aspects of communicative competence influenced by politeness strategies found in the English textbook. The interviews with the students revealed that the students also had similar thoughts as their teacher. But, based on the student interviews, it can be concluded that the aspects of communicative competence influenced by politeness strategies, found in the English textbook, are linguistic competence and strategic competence.

The results show that the teachers teach politeness generally. Since there is no specific point of politeness strategies in the curriculum, the teachers seemed to decide to explain that there are polite and impolite expressions in English depending on whom you speak with. The teachers carry out their obligation as a person who can decide the kind of language features their students have to learn (Macalister \& Nation, 2010). This finding is also supported by the students' answers in the interviews. The students said that their teachers explained politeness strategies in general, and what polite and impolite expressions are.

Another finding shows that cultural differences in politeness strategies have to be reflected in English textbooks. Because English is a foreign language in Indonesia, it should be in harmony with Indonesian culture in communication. As Kurdghelashvili (2015) and Mahmud (2019) stated, teachers have to be aware to draw students' consciousness towards cultural and power-related issues in using politeness strategies. Unfortunately, there is no previous study on this kind of power relation. The students also showed awareness of the power relation issue in polite 
strategies when they talked about polite expressions to use in communication with older people.

From the teachers' perspective, their students use negative politeness strategies after learning the expressions through the textbooks, showing the usefulness of including politeness strategies in the English textbooks. Gholami (2015) also found politeness strategies in Iranian EFL textbooks. Alcoberes (2016) revealed that Indonesian English textbooks contain materials which teach negative politeness. The students confirm this finding. The students also believed that the English textbook, which they use as a leaning source, include politeness strategies. However, based on the examples mentioned by the students, the researcher found that the English textbooks teach positive politeness, bald on-record, and off-record politeness strategies. These kinds of politeness strategies are based on Brown and Levinson's (1987) politeness theory.

The teachers perceive that politeness strategies in English textbooks may influence the students' communicative competence. They perceived that after the students learn politeness strategies, they will improve their communication skills, have better interpersonal communication, maintain harmonious relations, establish polite norms of communication, sustain the social relationship, and achieve the communicative goals (Adel et al., 2016; Flores-Salgado \& Castineira-Benitez, 2018; Kavanagh, 2016; Li, 2012; Maros \& Rosli, 2017).

The teachers also believed their students will reflect better attitudes after learning politeness strategies in the English textbook. It can relate to the student's probability of success, learning assistance, and interest will gain when the students treat in a polite way (Schneider et al., 2015). In this case, the students also agree that politeness strategies have authority and support their communicative competence. The students said that that they are more careful in selecting words, paying attention to their intonation, and considering how they have to behave in communication because of what they have learned about politeness strategies. It also makes them analyse their partner's reaction during the communication. The answers showed that the student's communicative competence is mostly in the linguistic competence and strategic competence. Linguistic competence is the essential elements of communication such as the sentence patterns and types, the knowledge of vocabulary, grammar, morphological inflection, semantic, and phonology (Littlewood, 2011). Then, strategic competence is the knowledge of communication strategies and how to use them. While some teachers are doubtful whether the politeness strategies can guide their students' communication, other teachers are confident that if their students practise the strategies, they can have effective interactions.

The results of this study can be used as a consideration for the teacher to be more aware of politeness strategies, especially when the teacher is in the process of selecting textbooks for learning references. The teachers have to consider politeness that are presented in the textbooks. Writers of English textbooks should also consider providing politeness materials in the textbooks since it is crucial for the students to develop communicative competence. 


\section{References}

Adel, S. M. R., Davoudi, M., \& Ramezanzadeh, A. (2016). A qualitative study of politeness strategies used by Iranian EFL learners in a class blog Iranian Journal of Language Teaching Research. Iranian Journal of Language Teaching Research, 4(1), 47-62.

Alcoberes, P. J. N. (2016). The author-initiated discourses in the selected english textbooks in southeast Asia: A world englishes paradigm. Asian Englishes, 18(1), 36-52.

Brown, P. (2015). Politeness and language. In J. Wright (Ed.), International Encyclopedia of the Social \& Behavioral Sciences ( $2^{\text {nd }}$ ed., Vol. 18, pp. 326-330). Amsterdam: Elsevier.

Brown, P., \& Levinson, S. C. (1987). Politeness: Some universals in language usage. Cambridge: Cambridge University Press.

Canale, M., \& Swain, M. (1980). Theoretical bases of communicative approaches to second language teaching and testing. Issues in Applied LinguisticsApplied LinguisticsApplied Linguistics, 1(1), 1-47.

Cunningsworth, A. (1995). Choosing your coursebook. Oxford: Macmillan Publishers Limited.

Edstrom, A., \& Ewald, J. D. (2019). Characteristics of effective auto-reply emails: Politeness and perceptions. Technology in Society, 58, 101112. https://doi.org/10.1016/j.techsoc.2019.01.005

Eghtesadi, A. R. (2017). Models of communicative competence: Implications for language teachers and teacher educators. ROSHD FLT, 31(3). Retrieved from https://www.roshdmag.ir/Roshdmag_content/media/article/40 from (95-96) MATN ZABAN 121-25_0.pdf

Fan, F. (2019). Cultivation of students' communicative competence in English teaching in higher vocational colleges under the background of international exchange and cooperation. Paper presented at 5th International Conference on Education Technology, Management and Humanities Sciences (ETMHS 2019). https://doi.org/10.25236/etmhs.2019.176

Fauziati, E. (2016). Applied Linguistics: Principle of foreign language teaching, learning, and researching. Surakarta: Era Pustaka Utama.

Flores-Salgado, E., \& Castineira-Benitez, T. A. (2018). The use of politeness in WhatsApp discourse and move "requests". Journal of Pragmatics, 133, 79-92. https://doi.org/10.1016/j.pragma.2018.06.009

Gholami, J. (2015). Is there room for pragmatic knowledge in english books in iranian high schools? English Language Teaching, 8(4), 39-51.

Graves, K. (2000). Designing I courses: A guide for teachers. Canada: Heinle \& Heinle Publisher.

Hymes, D. . (1972). On communicative competence. In J. Pride \& J. Holmes (Eds.), Sociolinguistis (pp. 269-293). Harmondsworth. UK: Penguin Book.

Kalymbetova, E., Kulsariyeva, A., \& Massalimova, A. (2015). Communicative competence of high school students. The European Proceedings of Social \& Behavioral Sciences. https://doi.org/10.15405/epsbs.2015.01.22

Kavanagh, B. (2016). Emoticons as a medium for channeling politeness within

Teacher's Perspective on the Impact of Politeness Strategies in the Indonesian English

Textbook on Student's Communicative Competence 
American and Japanese online blogging communities. Language and Communication, 48, 53-65.

Kurdghelashvili, T. (2015). Speech acts and politeness strategies in an EFL classroom in Georgia. World Academy of Science, Engineering and Technology International Journal of Social, Behavioral, Educational, Economic and Management Engineering, 9(1), 306-309.

Leech, N. G. (1983). Principle of Pragmatics. Longman. New York.

$\mathrm{Li}, \mathrm{M}$. (2012). Politeness strategies in Wiki-mediated communication of EFL collaborative writing tasks. IALLT Journal of Language Learning Technologies, 42(2), 1-26. https://doi.org/10.17161/iallt.v42i2.8510

Limberg, H. (2016). Teaching how to apologize: EFL textbooks and pragmatic input. Language Teaching Research, 20(6), 700-718.

Littlewood, W. (2011). Communicative Language Teaching: An Expanding Concept for a Changing World. In E. Hinkel (Ed), Handbook of research in second language teaching and learning. UK: Routledge.

Macalister, J., \& Nation, I. S. P. (2010). Language curriculum design. New York: Routledge.

Mahmud, M. (2019). The use of politeness strategies in the classroom context by English university students. Indonesian Journal of Applied Linguistics, 8(3), 597606.

Maros, M., \& Rosli, L. (2017). Politeness strategies in twitter updates of female english language studies Malaysian undergraduates. 3L: Language, Linguistics, Literature, 23(1), 132-149. https://doi.org/10.17576/3L-2017-2301-10

McConachy, T. (2018). Critically engaging with cultural representations in foreign language textbooks. Intercultural Education, 29(1), 77-88.

Pham, T. M. T., \& Yeh, A. (2020). Politeness of Vietnamese Students in Writing Request Email in English: a Course-based and Socio-pragmatic Study. International Journal of Language and Literary Studies, 2(2), 109-128. https://doi.org/10.1075/ijolc.1.1.00edi

Qian, D. D., \& Pan, M. (2017). Politeness in business communication: Investigating English modal sequences in Chinese learners' letter writing. RELC Journal, 50(1), 1-17. https://doi.org/10.1177/0033688217730142

Richards, J. C. (2017). Curriculum development in language teaching $\left(2^{\text {nd }}\right.$ ed.). New York: Cambridge University Press.

Saidi, M., \& Khosravi, M. (2015). EFL learners' perceptions of (im)politeness: The possible gender differences. International Journal of Language and Applied Linguistics, 1(1), 1-11. Retrieved from http://www.ijlal.ir

Schneider, S., Nebel, S., Pradel, S., \& Rey, G. D. (2015). Mind your Ps and Qs! How polite instructions affect learning with multimedia. Computers in Human Behavior, 51(PA), 546-555. https://doi.org/10.1016/j.chb.2015.05.025

Tsakona, V. (2016). Teaching politeness strategies in the kindergarten: A critical literacy teaching proposal. Journal of Politeness Research, 12(1), 27-54.

Whyte, S. (2019). Revisiting communicative competence in the teaching and assessment of language for specific purposes. Language Education \& Assessment, 2(1), 1-19. https://doi.org/10.29140/lea.v2n1.33

Teacher's Perspective on the Impact of Politeness Strategies in the Indonesian English Textbook on Student's Communicative Competence 